\title{
Sytuacja przemysłu nasiennego i hodowli roślin na Świecie i w Unii Europejskiej
}

\author{
The situation of the seed industry in the world and in the European Union.
}

\author{
Sławomir Podlaski ${ }^{\oplus}$, Chrystian Chomontowskiø
}

Instytut Biologii, Szkoła Główna Gospodarstwa Wiejskiego w Warszawie, ul. Nowoursynowska 166, 02-787 Warszawa,

$\triangle$ e-mail: chrystian_chomontowski@sggw.edu.pl

\begin{abstract}
Postęp naukowy w hodowli roślin oraz globalizacja produkcji nasiennej wpłynęły na gwałtowne zwiększenie wielkości handlu nasionami. Nasiona, obok pestycydów charakteryzują się w największym stopniu globalnym charakterem. W ostatnich latach obserwujemy postępującą koncentrację i monopolizację przemysłu nasiennego. „Wielka czwórka” firm nasiennych może decydować o losach światowej produkcji rolnej. W świecie w sektorze publicznym maleją nakłady na dział R\&D, rosną natomiast w sektorze prywatnym. Przemysł nasienny, obok farmaceutycznego jest najbardziej innowacyjnym sektorem gospodarczym. Średnie nakłady na prace B\&R wynoszą 17\% obrotu rocznie. Niektóre kraje europejskie (Dania, Holandia) uczyniły z przemysłu nasiennego narodową specjalizację.
\end{abstract}

Słowa kluczowe: hodowla roślin, nasiennictwo, przemysł nasienny, reprodukcja nasienna, Unia Europejska, Świat

Scientific progress in plant breeding and the globalization of seed production led to a rapid increase in the value of seed trade. Apart from pesticides, seeds are characterized by the most global character. In recent years, we have observed a progressive concentration and monopolization of the seed industry. „The big four” seed companies can decide the fate of global agricultural production. In the worlds public sector, expenditure on R\&D is decreasing, while in private sector it is growing. The seed industry, next to the pharmaceutical one, is the most innovative economic sector. Average R\&D expenditure is $17 \%$ of turnover per year. Some European countries like Denmark and the Netherlands have made the seed industry their national specialization.

Key words: plant breeding, seed science, seed industry, seed reproduction, European Union, World

Globalny charakter przemysłu nasiennego

Obecnie hodowla roślin i nasiennictwo funkcjonują nie jako oddzielny sektor gospodarki, ale pewien system organizacyjny, który w sumie tworzy tzw. przemysł nasienny lub po postępującej konsolidacji rynku, przemysł o życiu (przemysł 4.0). Przemysł nasienny obejmuje wzajemnie powiązane ze sobą i sprawnie działające elementy: hodowlę roślin, nasiennictwo, zaplecze naukowe (instytuty, uczelnie wyższe) ocenę odmian, ocenę nasion, banki, instytucje ubezpieczające. Ostatnio przemysł nasienny stopniowo przekształca się w przemysł o życiu zajmujący się wytwarzaniem towarów i usług gwarantujących wysoki poziom i bezpieczeństwo życia. W tym kontekście, oprócz wymienionych uprzednio elementów przemysłu nasiennego, w jego skład wchodzi przemysł farmaceutyczny i przetwórczy oraz bardzo zaawansowany przemysł dotyczący biologii molekularnej i syntetycznej. Pod względem własnościowym, liczący się w świecie narodowy przemysł nasienny, miał i będzie miał charakter prywatny. Wynika to nie ze względów doktrynalnych, ale jest warunkowane podstawowymi zasadami ewolucji przemysłu nasiennego, który wcześniej czy później z państwowego staje się prywatnym. Prywatyzacja daje nowy impuls rozwojowy dla przemysłu nasiennego. Zasada ta została potwierdzona ewolucją przemysłu nasiennego w wielu krajach, w tym najbardziej spektakularnie, w Indiach. W Indiach, po szerokim wejściu kapitału prywatnego do przemysłu nasiennego, w 1988 roku, roczny przyrost wartości rynku nasiennego w latach 2000-2012 był największy na świecie i wynosił $12 \%$ rocznie. Na rynek weszły również międzynarodowe firmy hodowlane, które przejęły udziały w indyjskich firmach. Kapitał prywatny zaangażowany był w hodowlę mieszańców i cennych rynkowo roślin warzywnych. Firmy państwowe zajmowały się hodowlą roślin samopylnych, których nasiona mogły być rozmnażane przez farmerów (Spielman i in., 2014).

Ostanie badania prowadzone przez OECD (2018), wykazały negatywny związek pomiędzy wielkością innowacji, mierzoną liczbą odmian 
wprowadzonych na narodowe listy, a liczbą hodowców zatrudnionych w sektorze publicznym. Każdy 1\% zwiększenia liczby hodowców w całkowitej ich liczbie zmniejszał liczbę odmian wprowadzonych na narodowe listy od 1,6 do $2,0 \%$. Co ciekawe, zależność ta nie była modyfikowana przez różny udział używanego materiału ze zbioru. Nasiona i pestycydy mają najbardziej globalny charakter ze wszystkich środków produkcji rolnej. Oznacza to, że są produkowane na świecie tam, gdzie jest to najbardziej opłacalne i dystrybuowane są w skali globalnej (rys. 1). Dotyczy to najczęściej nasion drobnych i drogich (mieszańce). Przykładowo, schemat globalnej produkcji nasion pomidora przedstawiono na rysunku poniżej.

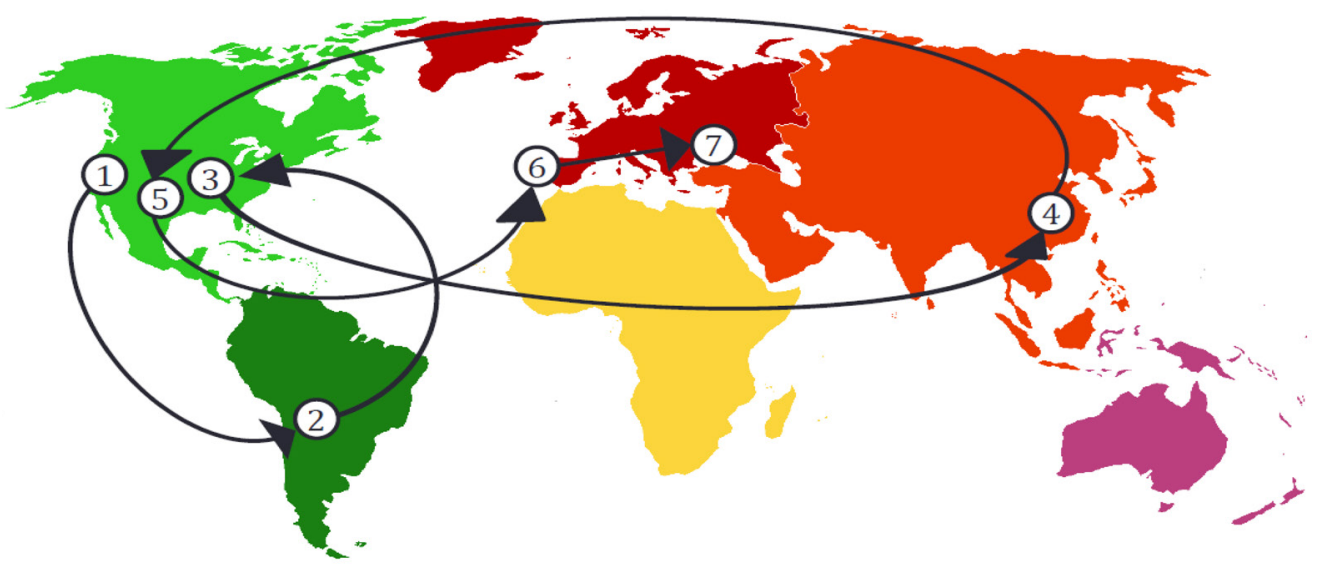

Rys. 1. Globalny schemat produkcji nasion pomidora: 1. Produkcja nasion w stopniu pre-basic (przed-elitarne), 2. Produkcja nasion w stopniu basic (elitarne), 3. Magazyn nasion, 4. Produkcja nasion kwalifikowanych, 5. Oczyszczanie, uszlachetnianie, pakowanie, 6. Dostawa nasion do głównego magazynu, 7. Dostawa do kraju finalnego przeznaczenia (Dunkle, 2015)

Fig. 1. Global Tomato Seed Production Scheme: 1. Pre-basic seed (pre-elite) production, 2. Basic seed (elite) production, 3. Seed storage, 4. Certified seed production, 5. Purification, processing, packaging, 6 . Delivery of seeds to the main warehouse 7. Delivery to the country of final destination (Dunkle, 2015)

W przypadku stosowania dużych norm wysiewu (wysadzania) i tanich nasion (ziemniaki, zboża), produkcja nasienna ma charakter lokalny, ze względu na duże koszty transportu. W stosunku do nasion wysiewanych przez polskich rolników, nasiona kwalifikowane zbóż (bez kukurydzy) wyprodukowane w Polsce stanowiły $90 \%$, nasiona roślin bobowatych grubonasiennych $99 \%$ oraz ziemniaków 89\% (Oleksiak, 2017). W obecnym czasie, nowe odmiany i nowe formy nasion, są podstawowym czynnikiem determinującym przyrost plonów. Agrotechnika wpływa na oszczędność środków produkcji, ich większą efektywność i precyzję stosowania oraz na zmniejszenie różnic pomiędzy plonem potencjalnym czy ekonomicznym a plonem uzyskanym na poziomie farmy. Dzięki temu ,inteligentne rolnictwo (smart farming)" może zwiększyć plony z jednostki powierzchni nawet o $25 \%$. Pomimo tego, to hodowla roślin i nowe odmiany będą głównym motorem zwiększenia produktywności (plonu potencjalnego) na poziomie rośliny i tym samym, przyrostu plonów i produkcji rolnej.

Znaczenie nasion, stanowiących początek procesu produkcji żywności, wpływa na rozwój rynków nasiennych i handlu nasionami. Wartość światowego rynku nasiennego, w latach 2015-16, według różnych ocen, wynosiła od 23,7 do 64,1 mld USD, natomiast roczny przyrost wartości światowego rynku nasion wahał się od 6,8 do $13,3 \%$. Największy wartościowy udział w rynku miały nasiona mieszańcowe $-28,4$ mld, następnie materiał siewny GMO o kilku zmodyfikowanych cechach (Bonny, 2017). Nasiona kukurydzy stanowią 40\% (20 mld USD) wartości globalnego rynku nasiennego, soi $14 \%$, ryżu około $10 \%$ (5 mld USD). Światowa wartość rynku warzyw oceniana jest na $4,7 \mathrm{mld}$ USD (około 9,5\%). Wśród warzyw dominują gatunki należące do rodziny psiankowatych (2 mld USD 
z czego $43 \%$ to pomidory, papryka i bakłażan), rynek warzyw korzeniowych ma wartość 0,8 mld USD, dyniowatych (melon, ogórek, arbuz, kabaczek 0,7 mld USD) (OECD 2018).

Wielkość rynku narodowego jest ściśle powiązana $\mathrm{z}$ efektywnością hodowli. Badania OECD (2018) wykazały, że każde zwiększenie wielkości rynku o $1 \%$ prowadzi do zwiększenia liczby odmian wpisanych na narodowe listy o $0,4-0,5 \%$. Wartość europejskiego rynku nasion była oceniana na $7 \mathrm{mld}$ $€ \mathrm{w} 2012$ roku. Zwiększenie wartości światowego rynku nasiennego jest ściśle powiązane $\mathrm{z}$ rozwojem handlu nasionami (rys. 2), który w ostatnich latach gwałtownie przyśpieszył.

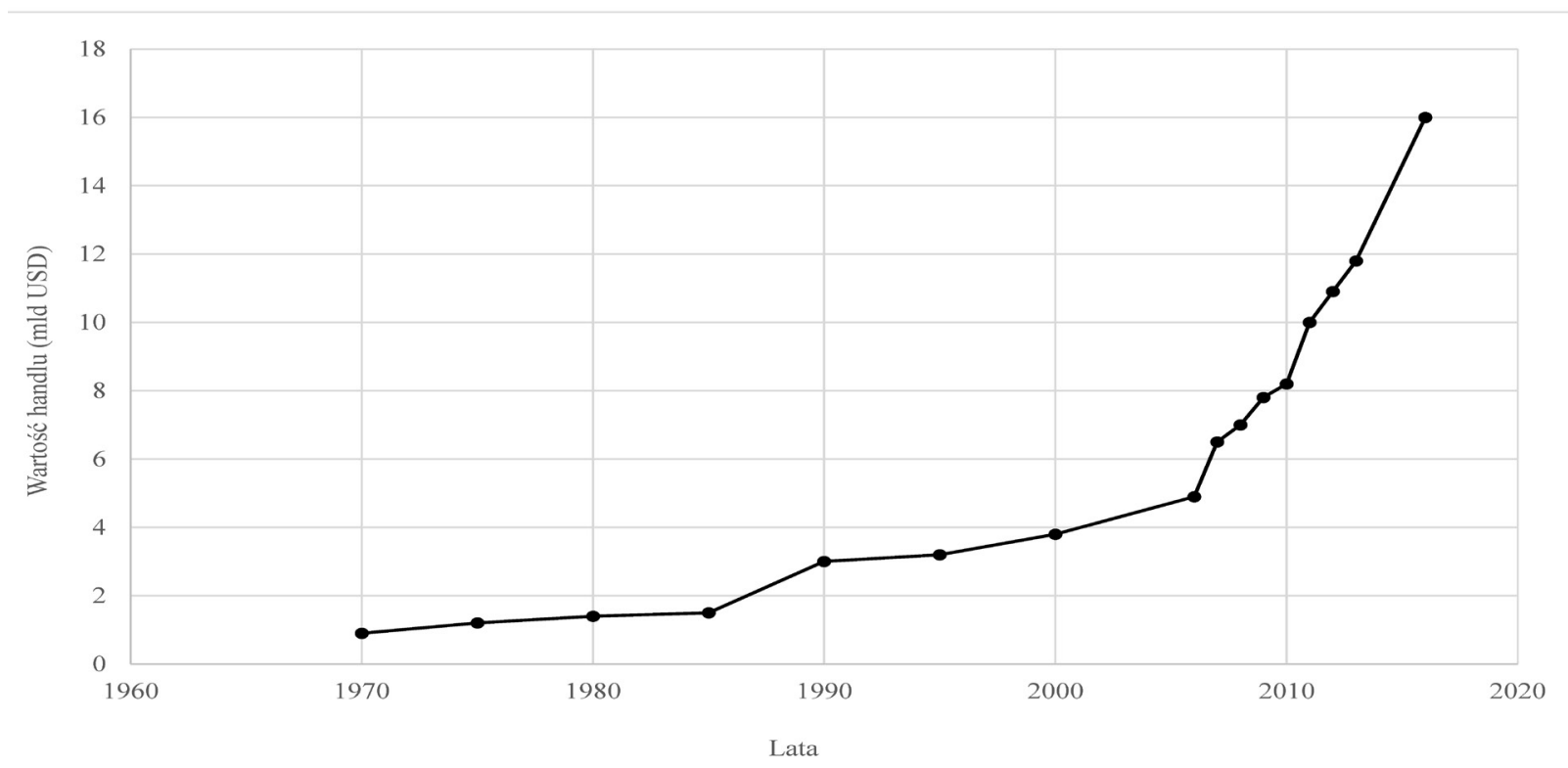

Rys. 2. Wartość światowego handlu nasionami w latach 1970-2016 (mld USD) (opracowanie własne na podstawie danych FIS)

Fig. 2. World seed trade value 1970-2016 (USD billion) (own study)

Handel nasionami obejmuje około 150 gatunków roślin. Nie ulega wątpliwości, że wzrost wartości rynków nasiennych oraz handlu nasionami powoduje zwiększenie konkurencji na rynkach narodowych i lokalnych. W tym kontekście należy zwrócić uwagę na rosnącą rolę wschodzących rynków nasiennych Chin, Brazylii i Indii (Tugendhat, 2014). Wartość tych rynków jest oceniana odpowiednio na 10, 2,6 i 2 mld USD a wartość eksportu nasion w 2012 roku wynosiła 251, 165 i $67 \mathrm{mln}$ USD. Dotychczasowy główny kierunek eksportu, to kraje afrykańskie, ale rośnie również eksport do Europy odmian reprodukowanych głównie w Chinach. Zwiększenie światowej reprodukcji nasion w Chinach wynika z taniej siły roboczej, dobrego klimatu do produkcji nasion oraz obecności na tych rynkach wielu dużych, w tym globalnych, firm nasiennych które organizują na miejscu produkcję nasienną. Równocześnie, w Chinach, Brazylii i Indiach, coraz silniej rozwija się narodowy sektor hodowli roślin.

\section{Czynniki decydujące o wzroście i ewolucji światowego przemysłu nasiennego}

Głównym elementem ewolucji przemysłu nasiennego jest postępująca jego koncentracja i internacjonalizacja. Pierwsze oznaki koncentracji w sektorze hodowli roślin pojawiły się w latach 60-70tych XX wieku. Od tego czasu proces ten uległ przyspieszeniu. Dane dotyczące wzrostu wartości sprzedaży nasion czołowych światowych firm nasiennych zamieszczono w tabeli poniżej (tab. 1).

Koncentracja przemysłu nasiennego może wpływać na jego monopolizację. Zależy to od rodzaju koncentracji: poziomej lub pionowej. Pozioma obejmuje firmy działające na tym samym rynku np. firmy nasienne. Pionowa to koncentracja firm o rożnym profilu działania np. nasienne i przetwórcze, czy wytwarzające komplementarne produkty np. chemiczne i nasiona. Koncentracja pozioma zwiększa konkurencję na rynku nasiennym, pionowa niekoniecznie. Jak wynika $\mathrm{z}$ tabeli 1 , wartość sprzedaży nasion firmy Monsanto w latach 
1996-2006, wzrosła o 7,1 mld USD, co daje $700 \mathrm{mln}$ USD rocznie. Dla porównania, firma KWS w tym samym czasie zwiększyła wartość sprzedaży o 665 mln USD czyli o $66,5 \mathrm{mln}$ USD rocznie. Liczby te wskazują na ekspansję ekonomiczną firm hodowlano-nasiennych. Jednocześnie widać, jak dobrym biznesem jest szeroko rozumiany przemysł nasienny i generalnie nasiona, jako środek produkcji.

Proces koncentracji firm hodowlanych ma charakter globalny. W Niemczech liczba firm zajmujących się hodowlą zbóż w latach 2005, 2010, 2015 i 2020 wynosiła czy będzie wynosić odpowiednio: 30, 27, 20 i 15 (Raport nasienny, 2018). We Włoszech w 1999 roku funkcjonowało 360 firm nasiennych w 2004 - 300, w 2009 - 270 i w 2013 - 220 (Narddi, 2016). Najszybsze i największe zmniejszenie liczby firm hodowlanych obserwujemy głównie w hodowli tych gatunków roślin, gdzie używa się dużych ilości nasion ze zbioru. Do takich gatunków należą głównie zboża, bobowate grubonasienne i ziemniaki. W Niemczech $w$ latach 2009-2014, liczba firm hodujących ziemniaki zmniejszyła się z 10 do 8 . Jednocześnie wzrosła liczba firm zajmujących się hodowlą roślin ozdobnych z 7 do 12, warzyw z 6 do 7 i roślin oleistych z 15 do 19 (Schäfer, 2010; Jorasch, 2014). Duże prywatne firmy hodowlane mają przewagę nad firmami z sektora publicznego, również w najbardziej rozwiniętych krajach świata. Posiadają one zimowe szkółki, duże szklarnie, najnowszą aparaturę, specjalistów z zakresu ochrony roślin, genetyki molekularnej, fizjologii i biochemii roślin, technologii nasiennej, marketingu a nawet specjalne zespoły grafików zajmujące się opracowaniem katalogów odmian. Hodowlę i ocenę materiałów hodowlanych prowadzą jednocześnie w wielu miejscach świata (Wolinsky, 2010).

Tabela 1

Table 1

Wartość sprzedaży (mIn USD) nasion dziesięciu czołowych firm hodowlano-nasiennych w latach 1985-2016 w stosunku do wartości światowego rynku nasiennego* (opracowanie wlasne)

Sales value (USD million) of seeds of ten leading breeding and seed companies in 1985-2016 in relation to the value of the global seed market* (own study)

\begin{tabular}{|c|c|c|c|c|c|c|c|c|c|c|c|}
\hline \multicolumn{3}{|c|}{1985} & \multicolumn{3}{|c|}{1996} & \multicolumn{3}{|c|}{2006} & \multicolumn{3}{|c|}{2016} \\
\hline Firma & $\begin{array}{l}\text { Mln } \\
\text { USD }\end{array}$ & $\%$ & Firma & $\begin{array}{l}\text { Mln } \\
\text { USD }\end{array}$ & $\%$ & Firma & $\begin{array}{l}\text { Mln } \\
\text { USD }\end{array}$ & $\%$ & Firma & $\begin{array}{l}\text { Mln } \\
\text { USD }\end{array}$ & $\%$ \\
\hline Pioneer & 735 & 4,1 & Pioneer & 1500 & 5,0 & Monsanto & 7297 & 17,4 & $\begin{array}{l}\text { Mon- } \\
\text { santo }\end{array}$ & 9988 & 20,0 \\
\hline Sandoz & 290 & 1,6 & $\begin{array}{l}\text { Novar- } \\
\text { tis }\end{array}$ & 900 & 3,0 & $\begin{array}{l}\text { Du Pont } \\
\text { Pioneer }\end{array}$ & 4700 & 11,2 & $\begin{array}{l}\text { Du Pont } \\
\text { Dow }\end{array}$ & 8188 & 16,4 \\
\hline Dekalb & 201 & 1,1 & $\begin{array}{l}\text { Lima- } \\
\text { grain }\end{array}$ & 650 & 2,2 & Syngenta & 2564 & 6,1 & $\begin{array}{l}\text { Syn- } \\
\text { genta }\end{array}$ & 2657 & 5,3 \\
\hline Upjohn & 200 & 1,1 & $\begin{array}{l}\text { Advan- } \\
\text { ta }\end{array}$ & 460 & 1,5 & Limagrain & 1155 & 2,8 & $\begin{array}{l}\text { Lima- } \\
\text { grain }\end{array}$ & 1746 & 3,5 \\
\hline $\begin{array}{l}\text { Lima- } \\
\text { grain }\end{array}$ & 180 & 1,0 & $\begin{array}{l}\text { Semi- } \\
\text { nis }\end{array}$ & 375 & 1,3 & KWS & 920 & 2,2 & KWS & 1506 & 3,0 \\
\hline Shell & 175 & 1,0 & Takii & 320 & 1,1 & $\begin{array}{c}\text { Land } \\
\text { O'Lakes }\end{array}$ & 550 & 1,3 & Bayer & 1427 & 2,9 \\
\hline Takii & 175 & 1,0 & Sakata & 300 & 1,0 & Bayer & 465 & 1,1 & DLF & 533 & 1,1 \\
\hline $\begin{array}{l}\text { Ciba } \\
\text { Geigy }\end{array}$ & 152 & 0,8 & KWS & 255 & 0,9 & Delta Pine & 417 & 1,0 & Sakata & 529 & 1,1 \\
\hline Sakata & 120 & 0,7 & Dekalb & 250 & 0,8 & Sakata & 410 & 1,0 & Takii & 480 & 1,0 \\
\hline KWS & 75 & 0,4 & $\begin{array}{l}\text { Mon- } \\
\text { santo }\end{array}$ & 170 & 0,6 & DLF & 365 & 0,9 & $\begin{array}{c}\text { Rijk } \\
\text { Zwaan }\end{array}$ & 431 & 0,9 \\
\hline Razem & 2303 & & & 4980 & & & 18843 & & & 27485 & \\
\hline Udział & & 12,8 & & & 17,4 & & & 45,0 & & & 55,2 \\
\hline
\end{tabular}

*wartość światowego rynku nasiennego: 1985 - 18, 1996 - 30, 2006 - 42, 2016 - 50 mld USD 
Czołowych 10 firm, decydowało o sprzedaży w 2016 roku 55,2\% nasion. Koncentracja sektora ciągle postępuje pomimo sprzeciwów

amerykańskich i europejskich urzędów antymonopolowych. W 2013 roku łączna sprzedaż nasion, agrochemikaliów i genetycznie zmodyfikowanych cech roślin wielkiej szóstki (Bayer, Dow, Monsanto, BASF, DuPont i Syngenta) sięgnęła 65 mld USD. W konsekwencji w 2013 roku firmy te kontrolowały $75 \%$ światowego rynku agrochemikaliów, 63\% nasion i wydatkowały więcej niż 75\% światowych nakładów na prywatne badania $\mathrm{w}$ sektorze $\mathrm{R} \& \mathrm{D}$ (Bonny, 2017). Ostatnia koncentracja doprowadziła do powstania w miejsce wielkiej szóstki, wielkiej czwórki, w wyniku połączenia następujących firm: Bayer i Monsanto, Dow i DuPont oraz ChemChina i Syngenta. Bayer został zmuszony do wycofania się $\mathrm{z}$ biznesu nasiennego na rzecz BASF oraz rezygnacji z produkcji nieselektywnego herbicydu Liberty. Dzięki temu, wartość sprzedaży nasion i cech biotechnologicznych BASF sięgnęła już 18\% całości rolniczej sprzedaży tej firmy. Coraz częściej sugeruje się, że koncentracja rynku środków produkcji dla rolnictwa wynika z rozpoczynającej się czwartej rewolucji rolniczej, opartej na technologii pozwalającej znacznie lepiej modyfikować procesy życiowe i cechy organizmów żywych oraz rozwoju „społeczeństwa informacyjnego” (Bonny, 2017). Wiek XXI, staje się czasem rozwoju biologii i technologii informatycznych, które znajdą zastosowanie w rolnictwie.

Konsekwencją opisanych powyżej połączeń firm, jest dalsze ekonomiczne ich wzmocnienie. Powstałe cztery duże firmy mogą w zasadniczy sposób decydować o losach światowego sektora hodowli roślin i nasiennictwa, forsując takie rozwiązania jakie im są wygodne np. wzmocnienie prawa własności intelektualnej do odmian czy przejście na amerykański system patentowy ochrony odmian.

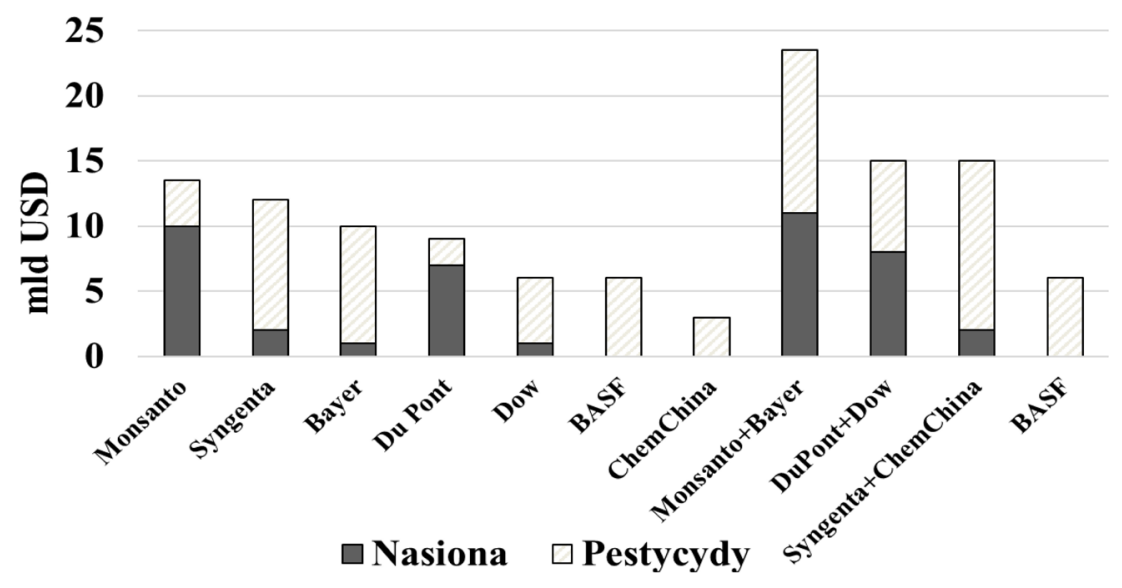

Rys. 3. Wartości produkcji nasion i pestycydów różnych firm przed i po połączeniach (Bonny, 2017)

Fig. 3. The values of seed and pesticide production of various companies before and after mergers (Bonny, 2017)

Dla farmerów, największe negatywne konsekwencje koncentracji firm hodowlanych, może mieć przewidywany wzrost cen nasion. W latach 1990-2010 w USA, ceny nasion podwoiły się w stosunku do cen uzyskanych przez farmerów za produkowane surowce. W Unii Europejskiej w latach 2000-2008, ceny materiału rozmnożeniowego wzrosły średnio o 30\%. Przeprowadzone symulacje wykazały, że wynikiem ostatniej koncentracji firm, może być wzrost ceny nasion kukurydzy od 1,5 do $7,0 \%$, soi od 1,0 do $6,5 \%$ oraz bawełny od 13,1 do 21,3\% (Bryant i in., 2016). Pomimo rosnących cen, udział kosztów nasion w całkowitych kosztach produkcji rolniczej nie jest duży i waha się w wybranych krajach UE od 2 do $15 \%$ (rys. 4). Duże różnice w udziale kosztów nasion w produkcji rolniczej poszczególnych krajów zależne są od wielu czynników, takich jak: struktura użytków rolnych (np. pastwiska czy łąki vs uprawy polowe), rodzaj nasion (mieszańce vs samopylne), stopień uszlachetniania, koszty produkcji nasiennej czy norma wysiewu. Nic dziwnego, że największy udział nasion w kosztach produkcji (ok. 15\%) obserwujemy w Holandii, gdzie dominują uprawy 
polowe i szklarniowe oraz nasiona mieszańcowe, w tym drogich warzyw, a najmniejszy w Irlandii (około 2\%), gdzie tyko $8 \%$ powierzchni użytków rolnych stanowią uprawy polowe a reszta to wieloletnie łąki i pastwiska. Pozytywnym trendem było zmniejszenie w UE udziału kosztów nasion w produkcji rolniczej w latach 2004-2012. W Polsce udział kosztów nasion w całkowitych kosztach produkcji rolniczej można ocenić na około 5,8\% (Wesseler i in., 2015).
Ponadto należy zwrócić uwagę, że bezwzględne koszty nasion kwalifikowanych na jednostkę powierzchni są bardzo zbliżone, przy zróżnicowanych plonach. Zjawiska tego nie obserwujemy w przypadku nawozów i środków ochrony roślin, gdzie chcąc zwiększyć plony musimy zwiększyć intensywność stosowania tych środków produkcji. W związku z tym najlepszym sposobem na obniżenie udziału kosztów nasion w całkowitych kosztach produkcji rolniczej jest maksymalizacja plonów.

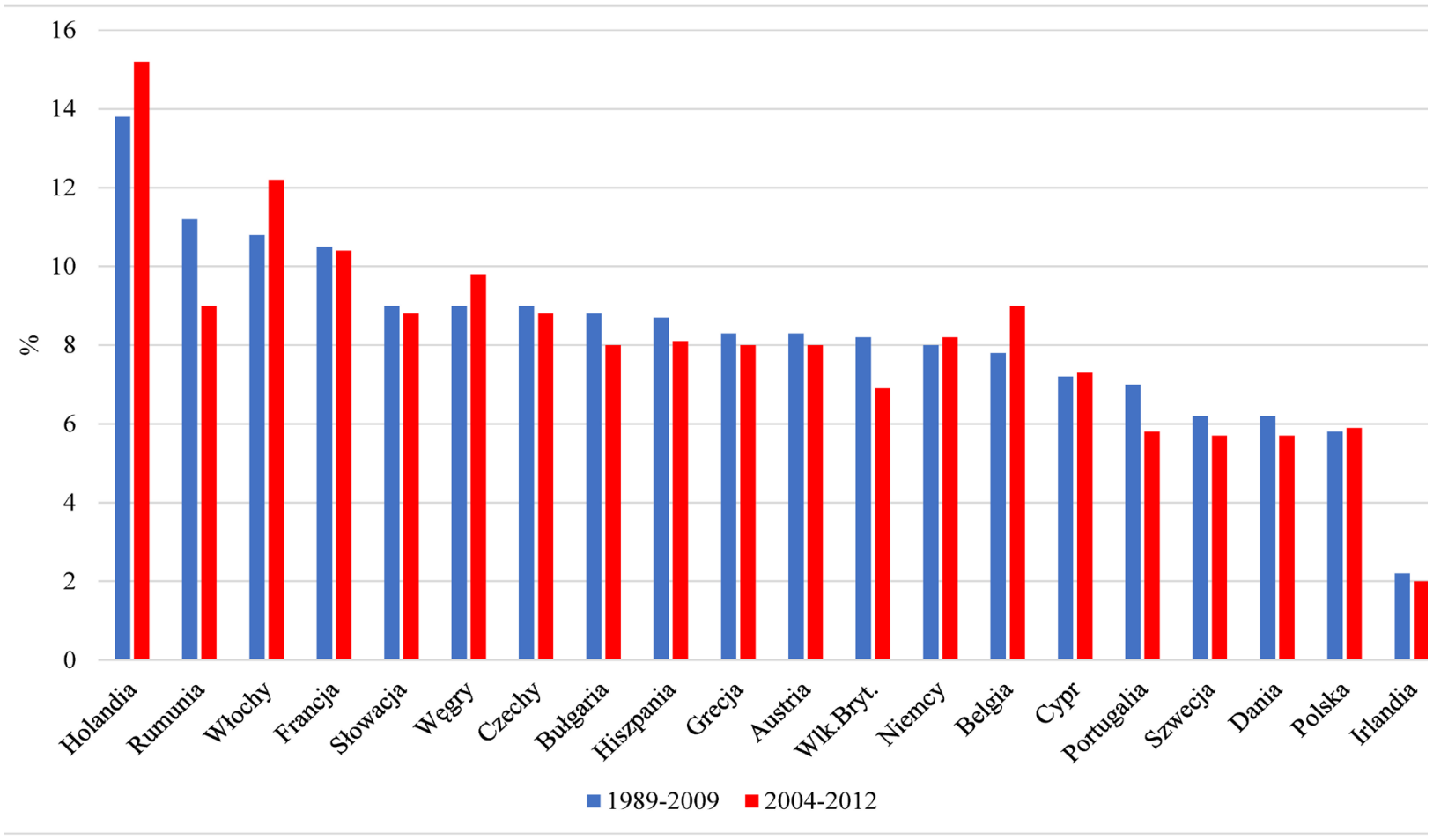

Rys. 4. Procentowy udział kosztów nasion w całkowitych kosztach produkcji rolniczej. Średnie dla krajów UE w latach 1989-2009 i 2004-2012 (Wesseler i in., 2015)

Fig. 4. The percentage share of seed costs in the total costs of agricultural production. Means for EU countries in 1989-2009 and 2004-2012 (Wesseler et al., 2015)

\section{Światowe finansowanie sektora $R \& D$ w ra- mach przemysłu nasiennego}

Analizę finansowania sektora R\&D można przeprowadzać w zależności od: pochodzenia i efektywności źródeł finasowania oraz sposobu finasowania. Wyróżniamy 3 źródła finansowania sektora nasiennego: ze źródeł własnych (prywatnych) firm hodowlano-nasiennych, z funduszy publiczno-prywatnych oraz ze źródeł publicznych. Najefektywniejsze jest finansowanie ze źródeł własnych firm hodowlano-nasiennych. Większość dużych firm posiada własne zaplecze naukowe, które realizuje badania na rzecz firmy. Efektywność sektora naukowego jest oceniana na zasadzie relacji pomiędzy nakładami a praktycznymi efektami naukowymi. Efekty badań najczęściej nie są publikowane. W Wielkiej Brytanii 89\% środków na badania pochodzi z własnych źródeł firm hodowlanych, pozostałe to fundusze obce. Wśród światowych prywatnych nakładów na badania naukowe, dotyczących szeroko rozumianej produkcji rolniczej, dominują wydatki na nasiona, rośliny zmodyfikowane genetycznie oraz pestycydy (rys. 5). Jednocześnie największy przyrost wartości nakładów pomiędzy latami 1994 i 2010 nastąpił w przypadku nasion i cech biotechnologicznych. 


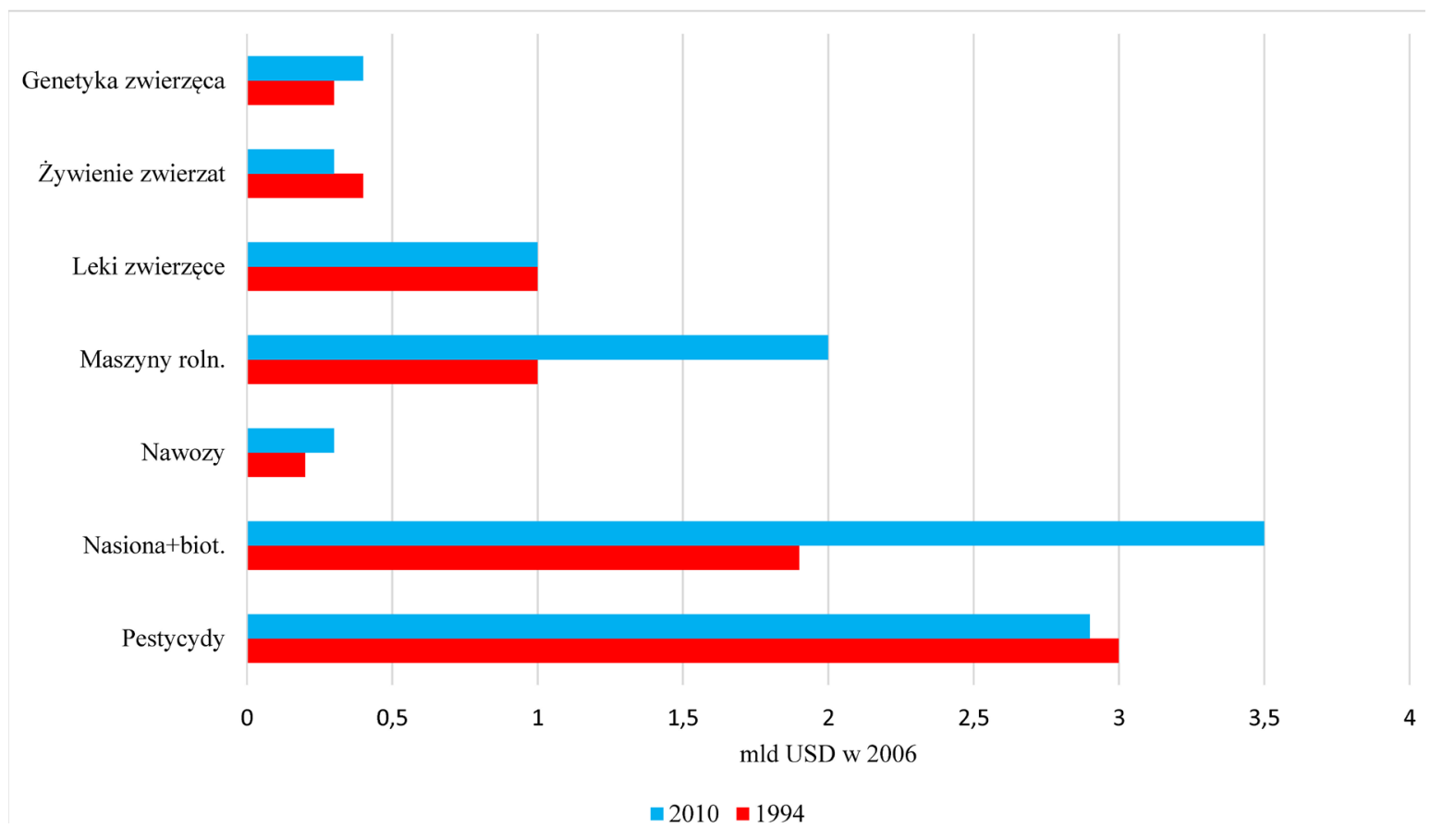

Rys. 5. Światowe pozapaństwowe wydatki na badania naukowe w różnych sektorach produkcji rolniczej w latach 1994 i 2010 (mld USD wg wartości w 2006) (Fuglie i in., 2011)

Fig. 5. World private research spending in various agricultural production sectors in 1994 and 2010 (USD billion by value in 2006) (Fuglie et al., 2011)

Z funduszy publicznych wspierane są prze- się zainteresowaniem sektora prywatnego. Sektor ważnie badania podstawowe, ochrona zasobów genowych, wytwarzanie materiałów wyjściowych (pre-breeding) i hodowla gatunków niecieszących prywatny zaangażowany jest głównie w praktyczną hodowlę tzw. cash crops (rośliny towarowe uprawiane dla czystego zysku) (rys. 6).

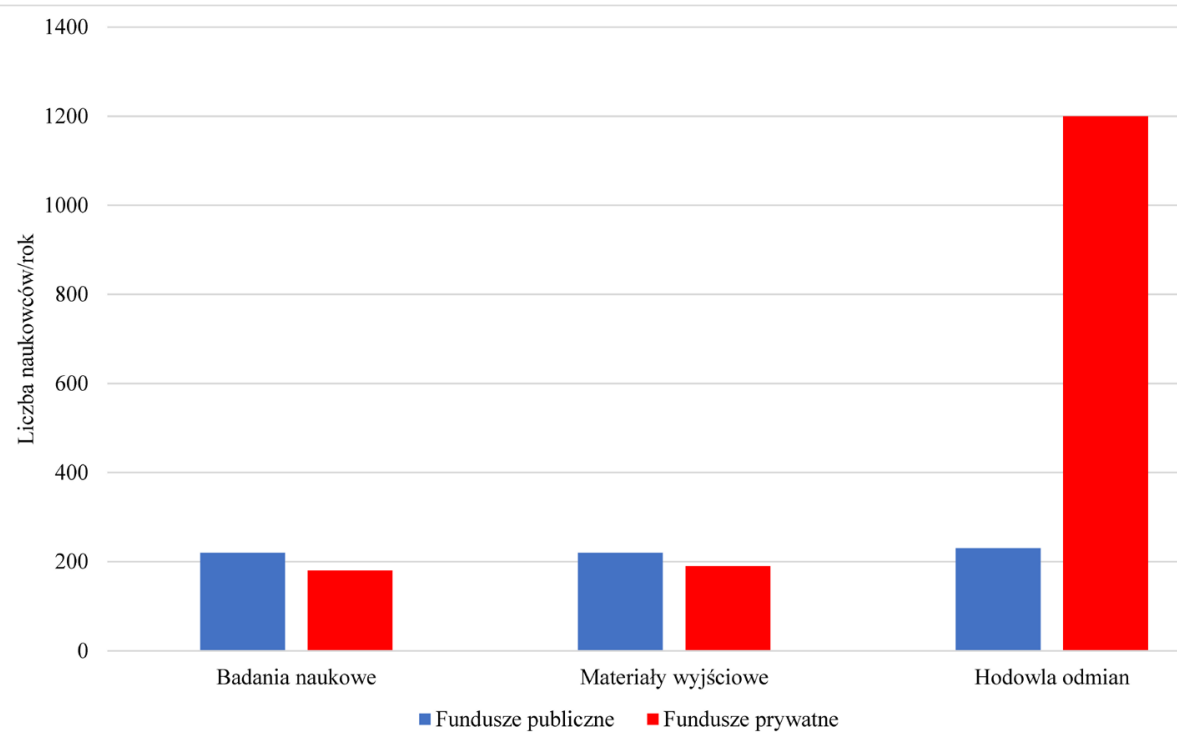

Rys. 6. Różna alokacja funduszy prywatnych i publicznych w USA, zależnie od etapów hodowli roślin (Fuglie and Walker, 2001)

Fig. 6. Different allocation of private and public funds in the US depending on the stages of plant breeding (Fuglie and Walker, 2001) 
W ramach funduszy publiczno-prywatnych finansowane są sieci naukowo-hodowlane oraz 15 globalnych centrów badawczych (CGIAR Consortium of International Agricultural Research Centers) zaangażowanych $\mathrm{w}$ szeroko rozumiane badania rolniczo-leśne oraz praktyczną hodowlę, głównie dla krajów rozwijających się. W Europie w Niemczech, przykładowymi sieciami nauko-hodowlanymi są: German Seed Alliance, realizujący hodowlę roślin w Rosji i dla Rosji, proWeizen Alliance for Wheat Research and Breeding, intensyfikująca hodowlę pszenicy czy różne Crop Genetic Improvements Networks w Wielkiej Brytanii. W krajach rozwiniętych, szczególnie w USA, obserwujemy wyraźną tendencję do zmniejszenia finansowania sektora hodowlanego z funduszy publicznych na rzecz prywatnych. Ten trend jest również obserwowany w największych krajach europejskich. W świecie istnieją co najmniej 2 sposoby zarządzania wprowadzaniem innowacji w przemyśle nasiennym: poprzez rynek oraz poprzez tworzenie sieci naukowo-hodowlanych, w ramach najczęściej partnerstwa publiczno-prywatnego. Pierwszy sposób dominuje w USA, gdzie panuje liberalna gospodarka, drugi jest typowy dla Europy w której poziom regulacji państwowych gospodarki jest większy niż amerykański.

Zasadniczym problemem jest ocena ekonomicznej efektywności finansowania działalności R\&D. Miernikami efektywności mogą być: wielkość całkowitych nakładów R\&D dla firm/firmy/ państwa, liczba uzyskanych patentów i „know -how" w wyniku działalności badawczej, zyski uzyskane w wyniku działalności R\&D wyrażające się liczbą uzyskanych odmian, ich jakości i długością życia $\mathrm{w}$ stosunku do nakładów. Przemysł nasienny charakteryzuję się wyjątkowo wysoką innowacyjnością, jedynie przemysł farmaceutyczny może z nim się równać. W 2018 roku w Niemczech i Holandii nakłady na sektor R\&D w przemyśle nasiennym, wynosiły średnio około $17-19 \%$ w stosunku do obrotu i stopniowo rosły. Natomiast firmy biotechnologiczne i niektóre holenderskie firmy hodowli roślin warzywnych, przeznaczają nawet $30 \%$ na prowadzone badania naukowe. Nakłady w sektorze R\&D różnych firm przedstawiono w tabeli poniżej (tab. 2).

Dzienne wydatki na sektor R\&D (mIn USD) różnych firm hodowlanych (opracowanie własne na podstawie raportów finansowych)

Daily R\&D spending (USD million) of various breeding companies (own study)

\begin{tabular}{cccc}
\hline Firma & 2008 & $2014-2016$ & 2017 \\
\hline Bayer & 8,5 & 11,1 & 14,0 \\
Monsanto & 2,6 & 4,4 & 4,4 \\
Syngenta & 2,5 & 3,7 & 3,6 \\
KWS & 0,09 & 0,52 & 0,61 \\
Limagrain & 0,19 & 0,50 & 0,51 \\
Polska & $\begin{array}{c}\text { Fundusz postępu } \\
\text { biologicznego }\end{array}$ & & 0,014 \\
\hline
\end{tabular}

Dla lepszego porównania, łączne finasowanie polskiej hodowli roślin z funduszu postępu biologicznego wynosiło w 2017 roku około 15,7 mln zł (5,1 mln USD) rocznie. Firma Monsanto wspiera dziennie swoją hodowlę podobną kwotą, jaką stanowiło roczne wsparcie dla polskiej hodowli roślin. Jednocześnie wielkość funduszu R\&D firmy Bayer była dokładnie 1000 razy większa niż polskiego funduszu postępu biologicznego.
Do różnicy w wielkości wsparcia naukowego należy dołączyć większą jego efektywność, wynikającą z faktu prywatnej własności obu firm. Dane dotyczące porównania wydatków na R\&D w holenderskim przemyśle nasiennym w porównaniu z innymi sektorami gospodarki oraz średnią dla przemysłu nasiennego Unii Europejskiej przedstawiono na rysunku poniżej (rys. 7). 


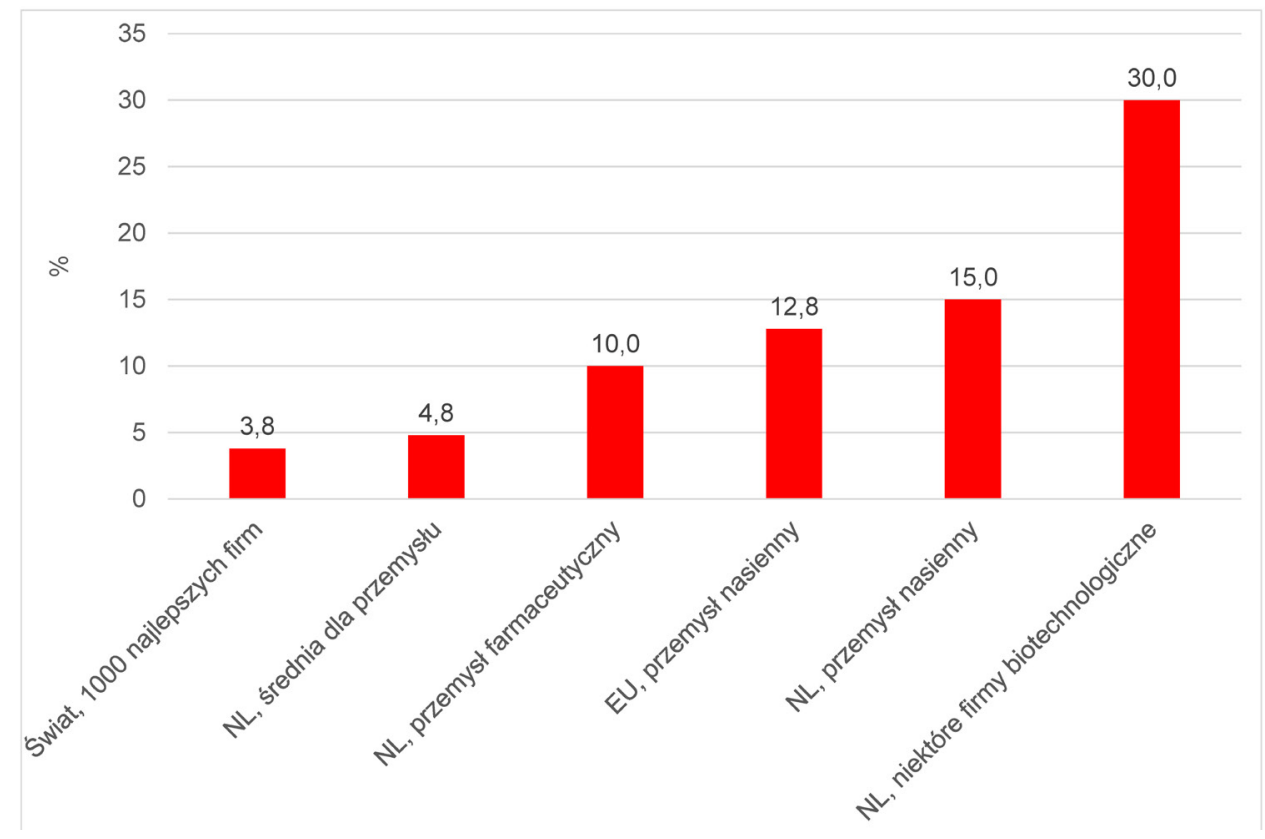

Rys. 7. Wydatki na badania i rozwój wyrażone w procentach obrotu w Holandii w 2009 roku (Bakker i in. 2012)

Fig. 7. Research and development expenditure as a percentage of turnover in the Netherlands in 2009 (Bakker et al. 2012)

Wydatki w sektorze R\&D przekładają się na nowe techniki i technologie hodowlane, a w konsekwencji na odmiany o specyficznych cechach. Ostatnio, do najbardziej spektakularnych osiągnięć, w tym względzie należą: uzyskanie odmian buraków cukrowych w oparciu o technologię Conviso Smart, coraz szersze upowszechnianie się odmian mieszańcowych zbóż oraz opracowanie nowej techniki hodowli ziemniaka $\mathrm{w}$ oparciu o botaniczne nasiona. Technologia Conviso Smart obejmuje dwa elementy: odmiany mieszańcowe buraka firmy KWS odporne na herbicydy z grupy ALS oraz herbicyd Conviso One, firmy Bayer. Odmianę uzyskano metodą selekcji miliardów komórek w kulturach komórkowych hodowanych na podłożu selekcjonującym, zawierającym herbicyd. Buraki uzyskano metodami konwencjonalnej technologii hodowlanej a efekt jest identyczny, jaki uzyskało Monsanto z technologią Roundup Ready® uzyskując organizmy GMO. Mieszańce zbóż stają się coraz bardziej popularne na rynkach światowych. Wynika to co najmniej z dwóch powodów: lepszych cech roślin w wyniku ujawnienia się efektu heterozji oraz konieczności corocznej wymiany nasion, co leży w interesie firm nasiennych. Obecnie po 35 latach (od 1984) pojawienia się w Europie pierwszych mieszańców żyta, odmiany hybrydowe tego gatunku bardzo się rozpowszechniły. W 2014 roku w Niemczech 81\% powierzchni żyta stanowiły mieszańce, w Danii stanowią one podstawową paszę dla świń. W 2017 roku w Polsce, udział odmian mieszańcowych żyta w rejestrze przekroczył $30 \%$ wszystkich odmian z czego tylko 3\% stanowiły formy krajowe (Oleksiak, 2017). W różnych krajach żyto mieszańcowe plonuje o 15-30\% lepiej niż odmiany syntetyczne czy populacyjne. W Polsce, w latach 2015, 2016 i 2017, 6 odmian żyta mieszańcowego firmy KWS plonowało średnio na wysokości $128,8 \%$, na poziomie agrotechniki a-1 (przeciętny poziom agrotechniki), a 7 odmian konwencjonalnych na poziomie $102,4 \%$. W pozostałych gatunkach zbóż, postęp hodowli mieszańcowej jest mniejszy, jednak jest to kwestia czasu, kiedy odmiany mieszańcowe wejdą do szerokiej uprawy. Holenderska firma Solynta zrewolucjonizowała sposób hodowli ziemniaka. Metodą chowu wsobnego uzyskano pełne wigoru diploidalne linie rodzicielskie. Linie te krzyżowano ze sobą pod kątem ich wartości kombinacyjnej uzyskując nasiona botaniczne mieszańców F1. Linie rodzicielskie drogą krzyżowania i selekcji zostały wzbogacone o pożądane cechy, jak np. odporność na zarazę ziemniaka. Dzięki wykorzystaniu nasion, hodowla skróciła się z 10 do 3 lat. Mieszańce są utrzymywane, produkowane i rozmnażane za pomoca nasion. $\mathrm{W}$ efekcie nie ma problemów $\mathrm{z}$ przenoszeniem chorób przez bulwy oraz kłopotów z logistyką. Dwadzieścia pięć gram nasion mieszczących się w małej kopercie zastępuje 2,5 t sadzeniaków, co starcza do obsadzenia 1 hektara. 


\section{Przemysł nasienny w Unii Europejskiej}

Rynek nasienny UE jest trzecim co do wielkości światowym rynkiem nasion po USA i Chinach i stanowi około $20 \%$ tego rynku. Jak wspomniano, jego wartość była oceniana na 7 mld $€$ a liczba firm w sektorze nasiennym ma sięgać 7000. Ta ostatnia liczba jest mocno przeszacowana, prawdopodobnie w tych dwóch krajach wliczono również stanowiska $\mathrm{z}$ nasionami w supermarketach i podobnych miejscach. W tabeli 3, zawarto wykaz firm o największej sprzedaży netto w UE. Jest ona bardzo podobna do listy światowej. Trzy największe europejskie firmy hodowlano nasienne, sprzedające nasiona na terenie Europy, mają wartość sprzedaży powyżej lub około 1 mld $€$, najmniejsze około $200 \mathrm{mln}$ $€$ (tab. 3).

W porównaniu do rynku światowego, rynek europejski jest mniej skoncentrowany i bardziej zróżnicowany pod względem wielkości (wielkość obrotów, liczby zatrudnionych) hodowanych gatunków roślin i zasięgu geograficznego aktywności hodowlanej. Występują jednak duże różnice w koncentracji rynku i udziale w nim poszczególnych firm hodowlano nasiennych. W przypadku 3 czołowych firm zajmujących się hodowlą buraków cukrowych, ich udział wynosi 79\%, w tym 39\% udziału ma KWS. Dla kukurydzy dane te wynoszą $56 \%$, a $22 \%$ udziału ma DuPont/Pioneer. Podobnie dość silnie skoncentrowany jest rynek warzyw. W hodowli pomidorów Monsanto ma 20\% udziału w rynku. Najmniej skoncentrowany jest rynek zbóż, ze względu na brak dużego udziału mieszańców i względnie niski udział nasion kwalifikowanych. Największy udział w rynku zbóż mają następujące firmy: Limagrain/Villmorin, KWS i RAGT. Mała koncentracja europejskiego rynku zbóż oznacza, że stosunkowo najłatwiej mogą na nim działać małe firmy nasienne.

Wartość sprzedaży netto (mln €) największych 10 firm europejskich (Wesseler i in., 2015)

Net sales value (million $€$ ) of the top 10 European companies (Wesseler et al., 2015)

\begin{tabular}{|c|c|c|c|c|c|c|c|c|}
\hline \multirow{2}{*}{ Firma } & \multicolumn{2}{|c|}{2010} & \multicolumn{2}{|c|}{2012} & \multicolumn{2}{|c|}{2013} & \multicolumn{2}{|c|}{2014} \\
\hline & $€$ & $\%$ & $€$ & $\%$ & $€$ & $\%$ & $€$ & $\%$ \\
\hline Du/Pont/Pioneer & 968 & 13,4 & 1419 & 16,5 & 1514 & 16,1 & 1467 & 14,3 \\
\hline Monsanto & 719 & 10,0 & 1006 & 11,7 & 1112 & 11,8 & 1164 & 11,3 \\
\hline Syngenta & 822 & 11,4 & 891 & 10,3 & 965 & 10,2 & 999 & 10,7 \\
\hline Limagrain/Vilmorin & 543 & 7,5 & 689 & 8,0 & 698 & 7,4 & 752 & 7,3 \\
\hline KWS & \multicolumn{2}{|c|}{$\begin{array}{c}480 \\
6,7\end{array}$} & 6,19 & 7,2 & 657 & 7,0 & 673 & 6,5 \\
\hline Bayer Crop Science & 351 & 4,9 & 428 & 5,0 & 428 & 4,5 & 460 & 4,5 \\
\hline DOW & 152 & 2,1 & 366 & 4,3 & 411 & 4,4 & 428 & 4,2 \\
\hline DLF Trifolium & 186 & 2,6 & 213 & 2,5 & 268 & 2,8 & 279 & 2,7 \\
\hline RAGT & \multicolumn{2}{|l|}{ bd } & \multicolumn{2}{|l|}{ bd } & \multicolumn{2}{|l|}{ bd } & \multicolumn{2}{|l|}{200} \\
\hline Euralis & \multicolumn{2}{|l|}{ bd } & \multicolumn{2}{|l|}{ bd } & \multicolumn{2}{|l|}{ bd } & \multicolumn{2}{|l|}{200} \\
\hline Land O'Lakes & \multicolumn{8}{|c|}{ Brak danych } \\
\hline Europejski rynek & 7217 & & 8616 & & 9414 & & 1028 & \\
\hline Rynek nasion UE & 6974 & & 7106 & & 7127 & & & \\
\hline
\end{tabular}


Koncentracja rynku buraków i warzyw będzie prawdopodobnie dalej rosła, dotyczyć to będzie także innych gatunków roślin. Motorem napędowym koncentracji rynku będzie zmniejszanie liczby firm hodowlano-nasiennych i konieczność zwiększania nakładów na badania naukowe (Wesseler, 2015).

Powierzchnia plantacji nasiennych w Unii Europejskiej w latach 2012-2017, wahała się od 1,91 do 2,03 mln ha. Francja, Włochy i Hiszpania są krajami charakteryzującymi się największą powierzchnią plantacji nasiennych (Tabela 4). W latach 2014-2017 nie zanotowano większych zmian w wielkości plantacji nasiennych w krajach Europy. Całkowita wartość nasion kwalifikowanych produkowanych na trenie UE sięga około 2,5 mld $€$. Z danych zawartych w tabeli 4 wynika, że niektóre kraje specjalizują się w produkcji nasiennej różnych gatunków roślin. Stanowi to pokaźne źródło dochodu farmerów i państwa. Dla przykładu Francja specjalizuje się w produkcji nasiennej zbóż, rzepaku oraz kukurydzy, Dania natomiast jest pierwszym producentem traw nasiennych na Świecie (40\% nasion traw i 70\% nasion mieszańcowych szpinaku pochodzi z tego kraju). Czechy są trzecim europejskim producentem nasion bobowatych (fasoli, grochu łubinów i wyki) uprawiającym plantacje nasienne na powierzchni 18,5 tys. ha. Pierwsze miejsce w tym względzie zajmują Włochy 61,7 tys. ha, a drugie Francja 35,5 tys. ha. Produkcja sadzeniaków na powierzchni 40,4 tys. ha to domena Holandii. Kraj ten jest dużym producentem nasion różnych gatunków roślin i surowych warzyw. Produkcja nasienna w Danii zajmuje aż 2,7\% powierzchni użytków rolnych tego kraju, w Holandii natomiast jest to $1,1 \%$. Eksport nasion holenderskich w 2014 roku, osiągnął wartość 3,1 mld €, natomiast sprzedaż zagraniczna świeżych warzyw wyrosłych $\mathrm{z}$ holenderskich nasion to wartość $7 \mathrm{mld}$ €. Z 1800 nowych odmian warzyw, pojawiających się corocznie na rynku UE, aż $65 \%$ pochodzi z Holandii. Dla porównania polski eksport nasion w 2016 roku wynosił w sumie $106 \mathrm{mln} €$, w tym warzywa $6 \mathrm{mln} €$, kwiaty $2 \mathrm{mln} €$ i rośliny rolnicze $98 \mathrm{mln} €$.

Charakterystyka produkcji nasiennej (bez warzyw i kwiatów) dziesięciu największych producentów nasion rolniczych UE w 2017 roku według ESCAA (European Seed Certification Agencies Association, 2017)

Characteristics of seed production (excluding vegetables and flowers) of the ten largest EU agricultural seed producers in 2017 according to ESCAA (European Seed Certification Agencies Association, 2017)

\begin{tabular}{cccccc|cccc}
\hline \multirow{2}{*}{ Państwo } & \multicolumn{5}{c|}{ Powierzchnia produkcji (tys. ha) } & \multicolumn{3}{c}{ Nasiona kwalifikowane tys.t. } \\
\cline { 2 - 9 } & Całkowita & Zboża & Rzepak & $\begin{array}{c}\text { Trawy } \\
\text { pastewne }\end{array}$ & $\begin{array}{c}\text { Kuku } \\
\text { rydza }\end{array}$ & Zboża & Rzepak & $\begin{array}{c}\text { Kuku } \\
\text { rydza }\end{array}$ & $\begin{array}{c}\text { Ziem- } \\
\text { niaki }\end{array}$ \\
\hline Francja & 354,1 & 143,6 & 9,8 & 13,1 & 59,3 & 494,0 & 17,8 & 212,6 & 612,8 \\
Włochy & 205,0 & 107,5 & 0,2 & 3,2 & 5,2 & 120,2 & bd & bd & 0,8 \\
Hiszpania & 185,2 & 117,1 & 1,9 & 3,5 & 1,2 & 270 & 0,3 & 5,1 & 30,9 \\
Niemcy & 171,4 & 106,7 & 2,6 & 24,7 & 3,7 & 764,7 & 20,0 & 25,6 & bd \\
Rumunia & 144,8 & 84,5 & 0,05 & 2,7 & 22,1 & 114,2 & 0,17 & 93,5 & 18,7 \\
Polska & 135,6 & 73,8 & 0,6 & 22,1 & 4,0 & 339,6 & 0,94 & 14,6 & bd \\
Dania & 131,3 & 52,8 & 0,7 & 69,1 & 0 & 22,2 & 0 & 0,07 & 1122,4 \\
Węgry & 107,1 & 36,4 & 0,7 & 5,2 & 21,3 & 152,0 & 2,7 & 103,9 & 2,9 \\
Czechy & 104,6 & 51,1 & 0,1 & 10,4 & 0,6 & 177,9 & 0,1 & 0,8 & 53,9 \\
UK & 94,7 & 59,3 & 0,4 & 6,0 & 0 & 285 & 1,0 & 0 & bd \\
Holandia & 60,6 & 3,9 & 0,0 & 13,7 & 0,02 & & & & \\
Razem \\
EU-28
\end{tabular}


Dane dotyczące Holandii i Dani wskazują, że dobrze zorganizowana hodowla roślin połączona $\mathrm{z}$ produkcją nasienną, może stać się ważnym elementem narodowej gospodarki. W latach 2014-2017 na rynku nasiennym EU wystąpiły ciekawe tendencje zmian $\mathrm{w}$ powierzchni upraw nasiennych. Powierzchnia upraw pszenicy miękkiej zmniejszyła się o: 69 tys. ha (12\%), jęczmienia o 45 tys. ha $(14,5 \%)$ i kukurydzy o 74 tys. ha $(36,1 \%)$ (rys. 8). Powierzchnia uprawy sadzeniaków ziemniaka zmieniała się w małym stopniu i wynosiła ok. 100-110 tys. ha. Obszar plantacji nasiennych słonecznika i rzepaku wahał się w granicach 50-58 tys. ha. Zwiększeniu natomiast z 337 do 445 tys. ha $(36,1 \%)$ uległy plantacje nasienne roślin pastewnych i traw. Jak już wcześniej wykazano (tab. 3) na rynku nasiennym UE, działa kilka dużych firm hodowlanych o zasięgu globalnym, niewielka liczba firm dużych i przeważająca liczba bardzo małych, małych i średnich przedsiębiorstw (tab. 5). Zwykle mniejsze firmy są zaangażowane bardziej w produkcję nasienną niż w hodowlę.

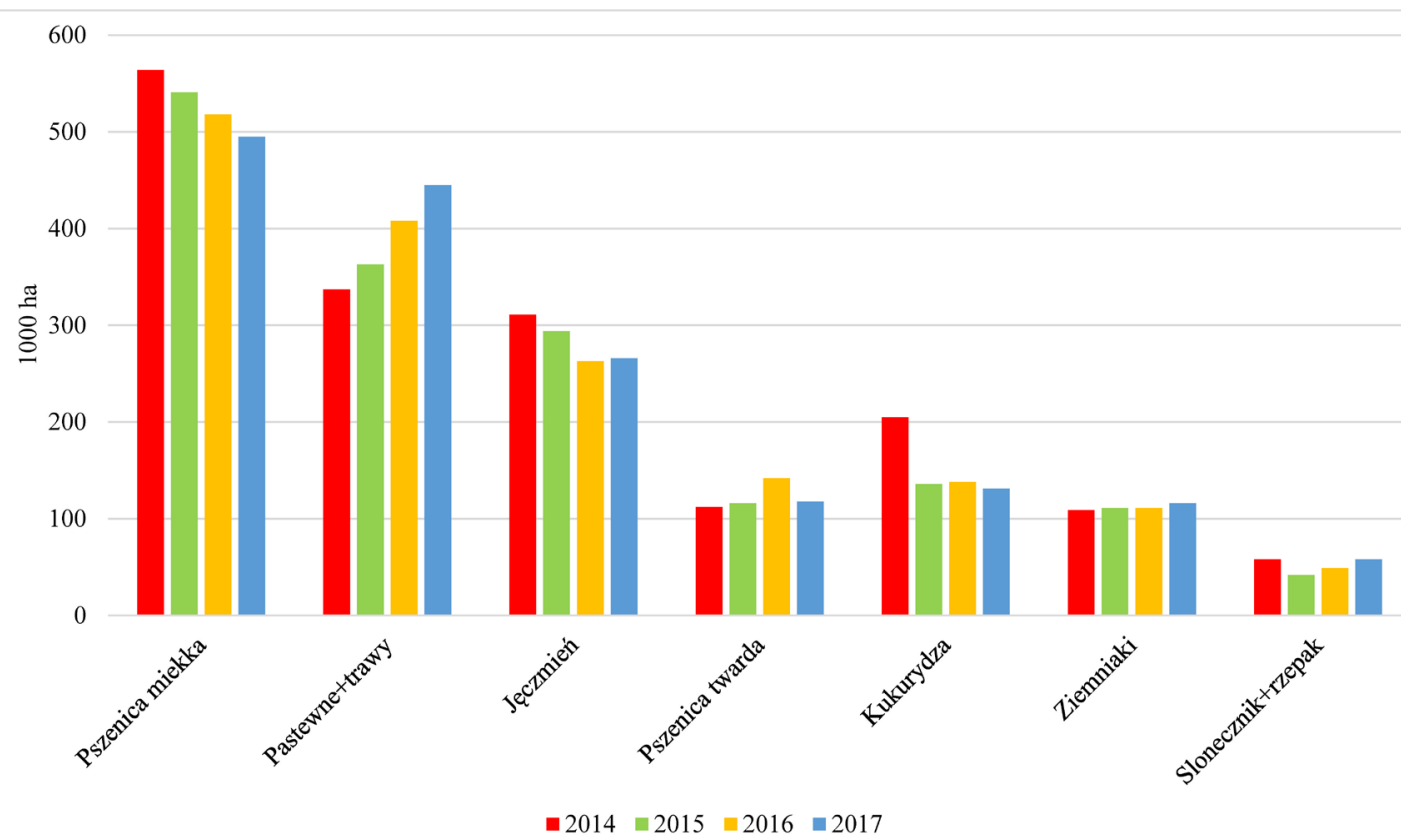

Rys. 8. Zmiany w powierzchni plantacji nasiennych UE w latach 2014-2017, wybranych gatunków roślin (ESCAA, 2017)

Fig. 8. Changes in the area of EU seed plantations of selected plant species in 2014-2017 (ESCAA, 2017)

Tabela 5

Table 5

Struktura przemysłu nasiennego w wybranych krajach europejskich (opracowanie własne)

The structure of the seed industry in selected European countries (own study)

\begin{tabular}{|c|c|c|c|c|c|c|}
\hline Państwo & $\begin{array}{c}\text { Liczba (szt.) } \\
\text { odmian rocznie } \\
\text { wyhodowanych }\end{array}$ & $\begin{array}{c}\text { Liczba firm } \\
\text { hodowlanych (szt) }\end{array}$ & $\begin{array}{l}\text { Udział wydatków } \\
\text { R\&D w obrocie\% }\end{array}$ & $\begin{array}{c}\text { Liczba firm } \\
\text { nasiennych } \\
\text { (szt) }\end{array}$ & $\begin{array}{l}\text { Rynek krajowy } \\
(\mathrm{mln} €)\end{array}$ & $\begin{array}{c}\text { Liczba } \\
\text { plantatorów } \\
\text { (szt) }\end{array}$ \\
\hline Francja & 550 & 70 & 13 & 246 & 2179 & 19000 \\
\hline Holandia & $1000-1200$ & $\begin{array}{c}100 \mathrm{R} \\
100 \mathrm{O} \\
130 \mathrm{OZ}\end{array}$ & $15-30$ & $300-350$ & 514 & 10000 \\
\hline Niemcy & 300 & 58 & 17 & 130 & 1000 & bd \\
\hline Dania & bd & bd & 15 & bd & 170 & 5000 \\
\hline Włochy & bd & bd & 13 & $\begin{array}{c}220 \mathrm{R} \\
80 \mathrm{O}\end{array}$ & $680-700$ & 17000 \\
\hline Szwecja & 30 & 10 & 13 & 13 & 195 & 1150 \\
\hline $\begin{array}{c}\text { Wielka } \\
\text { Brytania }\end{array}$ & 73 & $\begin{array}{l}23 \mathrm{RO} \\
13 \mathrm{OZ}\end{array}$ & 15 & 90 & 335 & \\
\hline
\end{tabular}


Warunkiem koniecznym dobrego funkcjonowania przemysłu nasiennego, jest jednakowy status wszystkich firm, bez preferencji, czy tym bardziej wsparcia ekonomicznego niektórych $\mathrm{z}$ nich. Z nierównym traktowaniem spotykamy się najczęściej wtedy, gdy na tym samym rynku nasiennym znajdują się nasiona wyprodukowane przez firmy państwowe, często wspierane różnymi dotacjami czy preferencjami w dostępie do materiałów wyjściowych i nasiona firm prywatnych bez takich możliwości. Firmy małe gwarantują spełnienie specyficznych żądań odbiorców nasion. Niekiedy żądania te są tak małe w wymiarze ekonomicznym, że dużym firmom nie opłaci się wchodzić na tak mały rynek. Ponadto przewaga firm lokalnych leży w znajomości lokalnych rynków, środków produkcji i niekiedy osobistej znajomości $\mathrm{z}$ odbiorcami nasion. Poprzez swą wielkość i mniejszą biurokrację, małe firmy są bardzo elastyczne, jeśli chodzi o reakcję na potrzeby rolników. W wielu przypadkach małym firmom trudniej funkcjonować ponieważ nie mają dużych możliwości a szczególnie rezerw finansowych. Ponoszenie długotrwałych strat finansowych, przez małą firmę, może doprowadzić do jej upadku, podczas gdy dla dużej pogarsza to jedynie ogólny bilans fiskalny. Firmy o małym i bardzo małym potencjale hodowlanym i ekonomicznym spełniają istotną rolę w prawidłowym funkcjonowaniu rynków nasiennych i w zaspokajaniu potrzeb rolników na określone odmiany czy gatunki roślin. Często firmy lokalne, współpracują z dużymi firmami hodowlanymi, kupując od nich komponenty hodowlane, wykorzystując ich osiągnięcia naukowe, czy podpisując umowy na wyłączność praw do odmiany. Małe firmy, w znacznie większym stopniu niż duże przedsiębiorstwa, zależne są od polityki Państwa wspierającego sektor hodowlany. Tylko wtedy, gdy Państwo udostępnia małym firmom kredyty, wyniki badań naukowych, a szczególnie wyprodukowane przez naukowe instytucje publiczne, materiały wyjściowe, lokalne firmy hodowlane mają szanse na rozwój.

Badania brytyjskie wykazały, że firmy małe (zatrudnionych mniej niż 50 osób, obrót mniejszy niż $10 \mathrm{mln}$ £), zajmują się głównie hodowlą odmian populacyjnych roślin samopylnych. Przeciętna firma jest właścicielem kilku odmian. Firmy małe, inwestują dziesięciokrotnie mniej w badania, niż firmy średnie (mniej niż 250 zatrudnionych, obrót poniżej $50 \mathrm{mln} €$ ). Głównym problemem tych firm jest brak kapitału.

\section{Podsumowanie}

Podsumowując można stwierdzić, że cechą charakterystyczną światowego przemysłu nasiennego jest jego postępująca globalizacja i koncentracja, co przekłada się na wzrost handlu nasionami i zwiększenie konkurencji na rynkach międzynarodowych i krajowych. Przemysł nasienny w porównaniu do innych działów gospodarki, jest najbardziej innowacyjny pod względem udziału nakładów R\&D w stosunku do sprzedaży czy obrotu nasionami. Brak efektywnego wsparcia przemysłu nasiennego przez badania naukowe ogranicza efektywność hodowli roślin. Firma Monsanto wydaje dziennie na prace hodowlane podobną kwotę, jak Polska na cały rok, firma Bayer posiada 1000 razy większy fundusz R\&D niż Polski Fundusz Postępu Biologicznego. Przemysł nasienny UE jest mniej skoncentrowany niż przemysł światowy. Niektóre kraje UE takie jak Holandia, czy Dania stworzyły z przemysłu nasiennego ważny element gospodarki narodowej.

\section{Literatura}

Bakker T., Dijkxhoorn Y., van Galen M. 2012. Plant reproduction materials, LEI, Wageningen UR, 12-012.

Bonny S. 2017. Corporate concentration and technological change in the global seed industry. Sustainability, 9, 1632, doi: 10.3390/su9091632.

Bryant H.A., Maisashvilli J., Outlaw J., Richardson J. 2016. Effects of proposed mergers and acquisitions among biotechnology firms on seed prices. Texas A\&M University, Agricultural and Food Policy Center p.35.

Dunkle R. 2015. Seed Phytosanitary Testing Issues: Industry Perspective. NAPPO, Phytosanitary Workshop, July, 28-29.

ESCAA (European Seed Certification Agencies Association).2017. Seed growing area in EU. http://www.escaa. org.

Fuglie, K., Walker, T. 2001. Economic Incentives and Resource Allocation in U.S. Public and Private Plant Breeding. Journal of Agricultural and Applied Economics, 33 (3), 459-473. doi: 10.1017/S1074070800020939

Fuglie K, Heisey P, King JL, Pray CE, Day-Rubenstein K, et al. 2011. Research investments and market structure in the food processing, agriculture input and biofuel industries worldwide. Rep. 130, ERS, US Dep. Agric.

Jorasch P. 2014. Public-private partnrschip in plant breeding research within Germany. Internatinal Workshop Public -private partnership on prebreeding.. Montpellier France, February 2-4.

Narddi M. 2016. The role of the seed sector in Italy for a modern and competitive agriculture. Italian J.Agronomy, 11 (2), 137-142, https://doi.org/10.4081/ija.2016.761. 
OECD 2018. Concentration in Seed Markets: Potential Effects and Policy Responses. OECD Publishing Paris. https:// doi.org/10.1787/9789264308367-3.

Oleksiak T. 2017. Rynek środków produkcji dla rolnictwa-stan i perspektywy. Analizy rynkowe nr 45.

Raport nasienny 2018. Ewolucja rynku nasiennego w Polsce.10 lat Top Farms Nasiona.

Schäfer C.S. 2010. Germaqn Seed Industry, Bundesverband Deutscher Pflanzenzuchter e.V. 29th ISTA Congress, Cologne.

Spielman D.J., Deepthi E., Kolady D.E., Cavalieri A., Rao Ch. N. 2014. The seed and agricultural biotechnology indu- stries in India: An analysis of industry structure, competition, and policy options. Food Policy 45, 88-100.

Wesseler J., Bonanno A., Drabik S., Materia V.C., Malaguti L., Meyer M., Venus T. 2015. Overview of the agricultural inputs sector in the EU. Directorate General for Internal Policies. Policy Department B: Structural and Cohesion Policies. European Union 2015.

Tugendhat H. 2014. Emerging Seed Markets: The Role of Brazilian, Chinese and Indian Seeds in African Agriculture. Future agricultures, Policy Brief 79, October.

Wolinsky H. 2010. Crop shortages. EMBO Rep.July; 11 (7): 508-510.doi: 10.1038/embor.2010. 87. 